\title{
Wharton's Jelly Mesenchymal Stromal Cells and Derived Extracellular Vesicles as Post-Myocardial Infarction Therapeutic Toolkit: An Experienced View
}

\author{
Noelia Muñoz-Domínguez ${ }^{1,+}$, Santiago Roura ${ }^{2,3,4,5,+}{ }^{,}$Cristina Prat-Vidal $2,3,4,6, *$ and Joaquim Vives ${ }^{1,7,8, *(1)}$ \\ 1 Servei de Teràpia Cel-lular, Banc de Sang i Teixits, Edifici Dr. Frederic Duran i Jordà, Passeig Taulat, 116, \\ 08005 Barcelona, Spain; noeliamunozdominguez@gmail.com \\ 2 ICREC Research Program, Germans Trias i Pujol Health Science Research Institute, Can Ruti Campus, \\ 08916 Badalona, Spain; sroura@igtp.cat \\ 3 Heart Institute (iCor), Germans Trias i Pujol University Hospital, Carretera de Canyet s/n, \\ 08916 Badalona, Spain \\ 4 CIBER Cardiovascular, Instituto de Salud Carlos III, 28029 Madrid, Spain \\ 5 Faculty of Medicine, University of Vic-Central University of Catalonia, 08500 Vic, Spain \\ 6 Institut d'Investigació Biomèdica de Bellvitge-IDIBELL, 08907 L'Hospitalet de Llobregat, Spain \\ 7 Musculoskeletal Tissue Engineering Group, Vall d'Hebron Research Institute (VHIR), \\ Universitat Autònoma de Barcelona, Passeig de la Vall d'Hebron 129-139, 08035 Barcelona, Spain \\ 8 Departament de Medicina, Universitat Autònoma de Barcelona, Passeig de la Vall d'Hebron 129-139, \\ 08035 Barcelona, Spain \\ Citation: Muñoz-Domínguez, N.; \\ * $\quad$ Correspondence: cprat@igtp.cat (C.P.-V.); jvives@bst.cat (J.V.); Tel.: +34-93-55-3050 (ext. 6353) (C.P.-V.); \\ +34-93-557-3500 (ext. 6708) (J.V.) \\ $\dagger \quad$ The first two authors (N.M.-D. and S.R.) contributed equally to this work.
} Roura, S.; Prat-Vidal, C.; Vives, J. Wharton's Jelly Mesenchymal Stromal Cells and Derived Extracellular Vesicles as Post-Myocardial Infarction Therapeutic Toolkit: An Experienced View. Pharmaceutics 2021, 13, 1336. https://doi.org/10.3390/ pharmaceutics13091336

Academic Editors: Edorta Santos-Vizcaino and Eun Seong Lee

Received: 9 July 2021

Accepted: 23 August 2021

Published: 26 August 2021

Publisher's Note: MDPI stays neutral with regard to jurisdictional claims in published maps and institutional affiliations.

Copyright: (c) 2021 by the authors. Licensee MDPI, Basel, Switzerland. This article is an open access article distributed under the terms and conditions of the Creative Commons Attribution (CC BY) license (https:/ / creativecommons.org/licenses/by/ $4.0 /)$.
Abstract: Outstanding progress has been achieved in developing therapeutic options for reasonably alleviating symptoms and prolonging the lifespan of patients suffering from myocardial infarction (MI). Current treatments, however, only partially address the functional recovery of post-infarcted myocardium, which is in fact the major goal for effective primary care. In this context, we largely investigated novel cell and TE tissue engineering therapeutic approaches for cardiac repair, particularly using multipotent mesenchymal stromal cells (MSC) and natural extracellular matrices, from pre-clinical studies to clinical application. A further step in this field is offered by MSC-derived extracellular vesicles (EV), which are naturally released nanosized lipid bilayer-delimited particles with a key role in cell-to-cell communication. Herein, in this review, we further describe and discuss the rationale, outcomes and challenges of our evidence-based therapy approaches using Wharton's jelly MSC and derived EV in post-MI management.

Keywords: biomanufacturing; cardiac tissue engineering; clinical translation; extracellular vesicles; mesenchymal stromal cells; myocardial infarction; Wharton's jelly

\section{Background}

Cardiovascular diseases remain the most common cause of mortality worldwide [1]. A long list of risks including sedentary lifestyle and obesity among other key factors are known to potentially harm de cardiovascular system [2]. Myocardial infarction (MI), caused by a lack of oxygen delivery to the myocardial tissue, is the most common cardiovascular disease which results in irreversible damage to the heart muscle that may impair cardiac function and lead to heart failure. Ultimately, heart transplantation is the last option to improve survival in end-stage heart failure although is hampered by the low number of organ donors and adverse allograft rejection [3]. Other limitations to reach complete heart function recovery include possible side effects of immune-suppressive drugs on other recipient's organs and the need for extremely complex coordinated procedures in expensive healthcare facilities $[4,5]$. 
Over the past few decades, this clinical scenario was spurred by initiatives addressing the design, development and assessment of a number of cell-based therapies to increase cardiac function recovery following MI [6]. In this context, the first efforts using mixed or enriched bone marrow mononuclear cell populations were extremely inefficient due to low cell retention, survival, and differentiation rates once administered. Further experiences were focused on intracoronary or intramyocardial delivery of mesenchymal stromal cells (MSC), also from bone marrow, subcutaneous adipose tissue or umbilical cord. Unfortunately, in general, treatment outcomes after conventional cell therapy in humans have been modest so far, because of the difficulties involved in repairing usually large myocardial scars and the low efficacy of administered cells [7]. Alternatively, cardiac tissue engineering (TE) emerged as a new therapeutic modality combining reparative cells with supporting materials (either natural or synthetic) in a three-dimensional (3D) context, although their clinical application is still very limited [8]. In present times, another strategy involving the use of extracellular vesicles (EV), which are double-layered membrane nanovesicles secreted by most cells to their microenvironment, has gained interest. In particular, EV secreted from multipotent mesenchymal stromal cells (MSC) are considered a valuable alternative to MSC themselves because they are potentially more efficient in transferring specific molecular cargoes and associated functions to targeted cells or tissues without the difficult logistics and safety risks associated with cell therapy. Thus, MSC-secreted EV (MSC-EV) may be useful immune-modulatory, cardioprotective and angiogenic agents post-MI, as shown in vitro and in experimental animal models $[9,10]$.

Herein, we review the scientific bases, current therapy toolkit and associated outcomes as well as the future challenges for the development of novel treatments using MSC-EV.

\section{Foundations of an Advanced Post-Myocardial Infarction Therapy \\ 2.1. Wharton's Jelly Mesenchymal Stromal Cells: The Active Ingredient}

Multipotent MSC are self-renewing, ex vivo culture-expandable stem cell populations that can be commonly collected from the stroma of almost all tissues and organs [11,12]. In regard to its origin, MSC arise most likely from the perivascular space [12]. According to the following minimal criteria established by the International Society for Cell and Gene Therapy (ISCT), MSC must show: (i) plastic-adherence under standard in vitro culture conditions; (ii) specific surface expression pattern including the presence of CD105, CD73 and CD90, and absence of CD45, CD14, CD79 $\alpha$ and HLA-DR; and (iii) in vitro ability to differentiate into mesodermal cell lineages (i.e., osteogenic, adipogenic and chondrogenic) [13]. In addition to their multipotent differentiation capacity, MSC also exhibit marked immune modulation potential and, thus, they are considered immuneprivileged [14-17].

Remarkably, the therapeutic potential of MSC lies in their capacity to secrete a myriad of paracrine factors into the microenvironment [18]. Mediators released by MSC are known to actively modulate diverse biological processes, including: (i) tissue regeneration and repair; (ii) progenitor cell differentiation; and (iii) immune/inflammatory responses [19]. In vivo, MSC are able to specifically migrate to damaged tissues, where they interact locally and regulate host reparative progenitors and/or immune cells (both from innate and adaptive immune systems) [20,21]. In this sense, MSC may induce functional changes of monocytes/macrophages, dendritic cells, T cells, B cells, and natural killer cells to regulate the overall immune system response [22]. This is, for instance, the case of MSC derived from the umbilical cord and the adipose tissue surrounding the human heart that equally inhibit the inflammatory response of stimulated T cells $[10,23]$. Despite the complexity of molecular pathways and immune cell types involved in immunologic disorders, the use of MSC for the treatment of patients with Graft versus Host Disease (GvHD) illustrates unequivocally their therapeutic potential, which can be further improved by generating pools of cells from different donors to ensure patient's response [24-26]. Thus, therapies based on MSC and derivatives will be developed along with increasing progress in understanding their intrinsic mechanisms of action (MoA), and may also benefit from recent trends 
towards the generation of regulatory-approved, clinical-grade cell banks with homozygous human leukocyte antigen (HLA) haplotypes of high prevalence among populations at a global scale [27]. This strategy holds the potential to offer optimized, versatile, immunecompatible therapeutic cell products for allogeneic transplantation.

Researchers already have the ability to readily isolate and scale-up large numbers of clinical-grade MSC from most tissue sources $[11,16]$. In particular, Wharton's jelly (WJ), which is a gelatinous substance of connective tissue found in the umbilical cord donated after birth, is a plentiful source of MSC [28,29]. Historically, WJ was first described by Thomas Wharton back in 1656 [30], whereas McElreavey and collaborators reported the isolation of MSC,WJ in 1991 [31] (Figure 1). In terms of baseline characteristics, MSC,WJ are quite primitive cells with low risk to carry somatic mutations, thus are considered highly immune-privileged in comparison with other potential tissue sources. Moreover, clinical application of MSC is not restricted by either invasive, painful isolation procedures or intrinsic donor comorbidities (i.e., cardiovascular risk factors). MSC,WJ also exhibit high proliferation rates ex vivo, therefore allowing well-established, valuable, clinicalgrade Master Cell and Working Cell Banks [16]. Notably, MSC,WJ express negligible levels of HLA-DR and low or null expression of the co-stimulatory molecules CD40, CD80 and CD86 [28,29]. Regarding HLA expression, we and others have previously demonstrated that HLA-DR expression is highly variable in primary MSC cultures, but it is almost undetectable in the case of MSC,WJ [28,32-34]. Additionally, their high secretion of inhibitory molecules such as PGE2 and the expression HLA-G6 isoform support the abovementioned immune-privileged status by MSC,WJ [14]. Altogether, these data support the low probability of rejection and low toxicity of MSC,WJ once administered [35]. In this sense, in our laboratory, we confirmed that MSC,WJ are clinically useful and safe in the context of inflammatory conditions, including chronic spinal cord injury (EudraCT No. 2015-005786-23; ClinicalTrials.gov (accessed on 30 June 2021) Id. NCT03003364) and severe respiratory distress due to SARS-CoV-2 infection (EudraCT No. 2020-001505-22; ClinicalTrials.gov (accessed on 30 June 2021) Id. NCT04390139) [36,37].

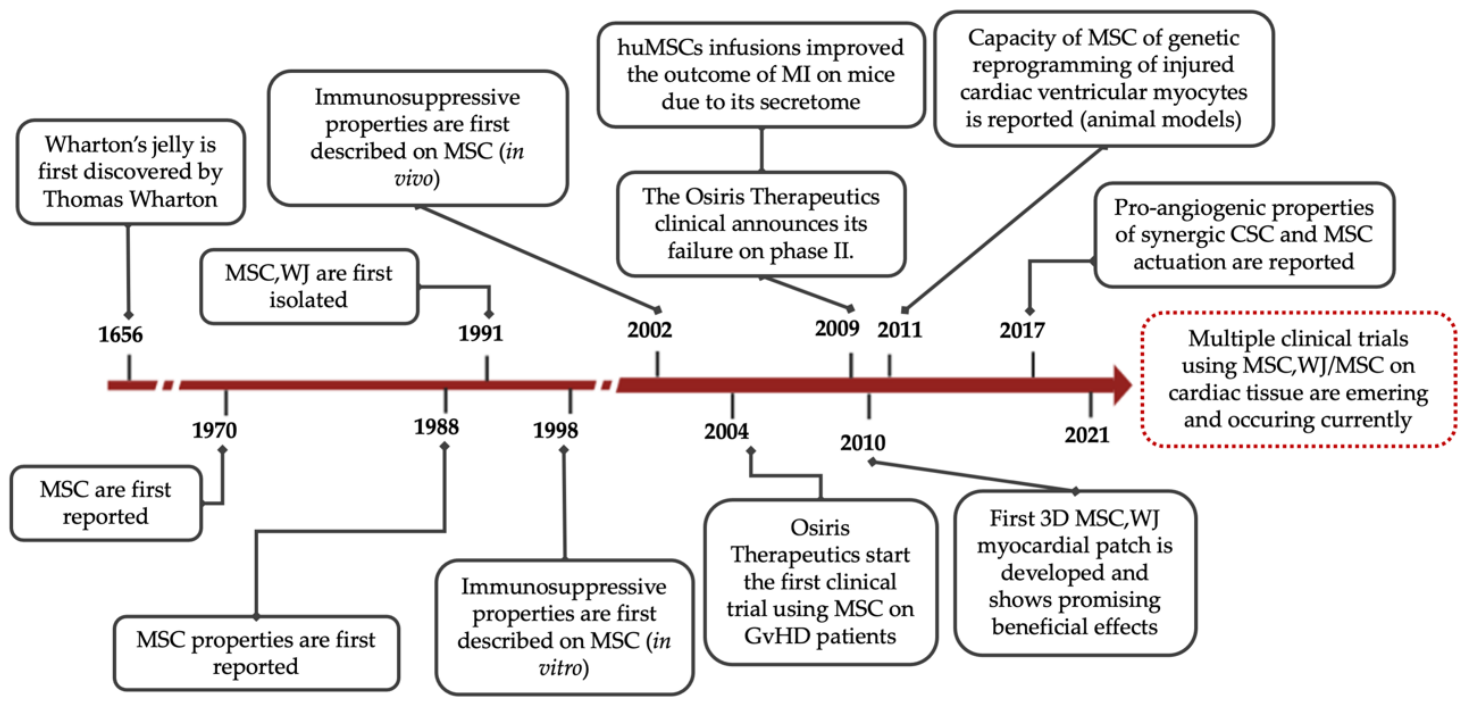

Figure 1. Timeline with major milestones in MSC research. MSC = Mesenchymal Stromal Cells; MSC,WJ = Wharton's jellyderived Mesenchymal Stromal Cells; CSC = Cardiac Stem Cells; GvHD = Graft-versus-Host Disease; MI = myocardial infarction .

\subsection{Cardiac Extracellular Matrices: The Supportive Vehicles}

Cardiac TE offers a plausible solution to overcome therapeutic limitations observed when reparative cells are delivered into the hypoxic infarcted area by either intracoronary administration or direct myocardial injection, thus increasing their cellular implantation and survival rates [38]. Furthermore, the use of supportive vehicles allows the incorpo- 
ration of cells and/or bioactive factors for prolonged local retention and facilitates their biological activity or MoA. In brief, a variety of natural and synthetic materials have been used as cell supportive platforms generating engineered bioimplants or grafts that can be securely implanted over the post-infarcted heart [39]. Nevertheless, natural materials show enhanced biodegradable and biocompatible properties and can better recreate the native myocardium environment [40,41]. Particularly, the decellularized cardiac extracellular matrix (ECM) provides a close match to the native, physiological microenvironment with minor changes in stiffness while preserving the composition, vasculature network and 3D framework [42], while also enabling electromechanical coupling with the host myocardium after implantation $[43,44]$. For that, porosity and pore size are critical parameters for the functionality of decellularized scaffolds and determine their optimal mechanical properties, among other paramount factors [45]. Hence, the presence of open porous and interconnected networks is crucial to guarantee optimal cell nutrition, proliferation and migration for successful tissue repair and regeneration [45].

In our laboratory, a refined protocol for the manufacture of porous decellularized cardiac ECM from the human pericardium and porcine myocardium loaded with cardiac adipose tissue-derived MSC (MSC,CAT) was reported [46,47]. According to our observations, both decellularized porous scaffolds: (i) were optimal for accommodating host-derived cells; (ii) provided the necessary signalling cues to modulate cell function; and (iii) highly supported cell differentiation and survival $[46,47]$. However, proteome characterization of the two decellularized matrices showed enrichment of matrisome proteins and major cardiac ECM proteins, considerably higher for the recellularized pericardial graft. Moreover, although macro and micromechanics were well-maintained in both cardiac ECM following decellularization, the decellularized pericardial scaffold demonstrated improved cell infiltration and retention as well as larger pore size, making it the preferred scaffold for the biofabrication of solid organs or bioimplants [48,49]. Interestingly, decellularized ECM can be subjected to lyophilisation or sterilization procedures without significant mechanical changes, thus allowing their storage until use as off-the-shelf products for clinical use $[49,50]$.

\subsection{Evidence-Based Pre-Clinical Outcomes}

In our laboratory, we collected robust in vivo data regarding the use of our two previously-described decellularized ECM in post-infarcted swine models. First, the neoformation of growing blood vessels and sprouting nerves in cardiac ECM made of decellularized pericardium once implanted in post-infarcted pigs suggested that: (i) both vascularization and innervation processes were supported by the ECM structure itself; (ii) were hypoxia-dependent; and (iii) required mobilization of host undifferentiated progenitor cells $[49,50]$. Second, implantation of cell-embedded cardiac bioimplants limited the sequelae associated with $\mathrm{MI}$, particularly reducing infarct size and improving cardiac function. In these experiments, we specifically repopulated the decellularized human pericardial ECM by combining porcine MSC,CAT with the self-assembling peptide RAD16-I to generate optimal 3D conditions that efficiently promoted proliferation, maintained the differentiation commitment of MSC,CAT toward the endothelial lineage, and increased their migration from bioimplant to underlying injured myocardium [46]. Cardiac function was further assessed non-invasively by magnetic resonance imaging (MRI) and scar healing was evaluated by using a customized-design electrical impedance spectroscopy monitoring system incorporated within the bioimplant [51]. As a result, MRI detected a significant improvement in left ventricular ejection fraction (LVEF) and stroke volume in bioimplant-treated animals while morphometric measurements revealed a significant reduction in infarct size one month after implantation. Interestingly, we confirmed that noninvasive electrical impedance spectroscopy was useful for tracking differential scar healing, showing differences in impedance parameters between treated and control pigs. Indeed, myocardial tissue was preserved in bioimplant-treated animals, which was con- 
firmed by histopathological measurements of reduced inflammation and altered collagen deposit [51].

Alternatively, administration of a similar ECM-based cardiac bioimplant combining decellularized porcine myocardial ECM refilled with porcine MSC,CAT also supported cardiac recovery in post-infarcted pigs. Our results reflected a higher improvement in LVEF after MI in the porcine myocardial ECM bioimplant-treated animals compared to those carrying the same cell-free scaffold [44] or other types of natural scaffolds [52,53]. Furthermore, engrafted bioimplant promoted revascularization of injured tissue, reduced infarct size, and attenuated ventricular remodeling and fibrosis progression [54].

A concluding comparison of functional benefits associated with the two decellularized ECM-based bioimplants was additionally reported by our group, as described in [49]. Additionally, decellularized scaffolds were either repopulated with porcine MSC,CAT or tested as cell-free scaffolds. Irrespective of the ECM origin or cell recolonization, both TE constructs were found well-integrated with the underlying myocardium and showed signs of neovascularization and nerve sprouting forty days after implantation. The combination of decellularized ECM scaffolds with MSC showed higher improvement than the cell-free scaffolds, indicating a synergistic effect of all bioimplant components in the therapeutic benefit of TE products [55]. Indeed, TE scaffolding may be beneficial for triggering MI recovery by providing a favorable microenvironment for the recruitment of endogenous progenitor cells towards the infarct bed by embedded MSC. The contribution of MSC to MI recovery has been previously reported [56], and paracrine signaling has been broadly described as one of the putative mechanisms by which implanted MSC can exert beneficial effects over the infarcted area $[57,58]$.

Collectively, the presented evidence-based pre-clinical experience using MSC and cardiac ECM supports the achievement of beneficial effects on cardiac function following MI [59-63]. This was shown to be crucial for the regulatory approval of a novel advanced therapeutic medicinal product (ATMP) termed PeriCord by the Spanish Agency of Medicines and Medical Devices (AEMPS) (PEI18-140). PeriCord, which is composed of regulatory-approved MSC,WJ (PEI16-017) within decellularized pericardial ECM, potentially emerges as a new generation of TE-based treatment for MI. For that, its safety and efficacy are being evaluated in the clinical setting (Table 1) [64].

Table 1. Current clinical trials with using MSC,WJ or EV in the treatment of cardiovascular diseases. * Reported results in [65].

\begin{tabular}{|c|c|c|c|c|c|c|}
\hline Clinical Trial & Identifier & Abstract & $\mathbf{N}$ & Drug & Phase & State \\
\hline $\begin{array}{l}\text { Pericardial Matrix } \\
\text { With Mesenchymal } \\
\text { Stem Cells for the } \\
\text { Treatment of Patients } \\
\text { With Infarcted } \\
\text { Myocardial Tissue } \\
\text { (PERISCOPE) [50] }\end{array}$ & NCT03798353 & $\begin{array}{l}\text { Comparison of the } \\
\text { outcome of patients } \\
\text { who have undergone } \\
\text { sternotomy to } \\
\text { perform surgical } \\
\text { revascularization and } \\
\text { patients that, } \\
\text { additionally, were } \\
\text { implanted the } \\
\text { PeriCord construct }\end{array}$ & Estimated: 12 & $\begin{array}{l}\text { Matrix-cell } \\
\text { construct placed } \\
\text { in the ischemic } \\
\text { area (PeriCord) }\end{array}$ & 1 & Recruiting \\
\hline $\begin{array}{c}\text { Intracoronary } \\
\text { Human Wharton's } \\
\text { jelly-derived } \\
\text { Mesenchymal Stem } \\
\text { Cells (MSC,WJ) } \\
\text { Transfer in Patients } \\
\text { With Acute } \\
\text { Myocardial } \\
\text { Infarction (AMI) } \\
\text { (MSC,WJ-AMI) [65] }\end{array}$ & NCT01291329 & $\begin{array}{l}\text { Evaluation of safety } \\
\text { and efficacy of } \\
\text { MSC,WJ infusion in } \\
\text { patients } 4-7 \text { days } \\
\text { post-MI }\end{array}$ & 116 & $\begin{array}{l}\text { MSC,WJ infusion } \\
\text { or placebo }\end{array}$ & 2 & $\underset{*}{\text { Completed }}$ \\
\hline
\end{tabular}


Table 1. Cont

\begin{tabular}{|c|c|c|c|c|c|c|}
\hline Clinical Trial & Identifier & Abstract & $\mathbf{N}$ & Drug & Phase & State \\
\hline $\begin{array}{l}\text { Randomized Study } \\
\text { of Coronary } \\
\text { Revascularization } \\
\text { Surgery With } \\
\text { Injection of MSC,WJ } \\
\text { and Placement of an } \\
\text { Epicardial } \\
\text { Extracellular Matrix } \\
\text { (scorem-cells) }\end{array}$ & NCT04011059 & $\begin{array}{l}\text { Evaluation of the } \\
\text { safety and effect of } \\
\text { intramyocardial } \\
\text { injection of MSC,WJ } \\
\text { in coronary } \\
\text { revascularization }\end{array}$ & Estimated: 40 & $\begin{array}{l}\text { MSC,WJ injection } \\
\text { or placebo }\end{array}$ & $1-2$ & $\begin{array}{l}\text { Not yet } \\
\text { recruiting }\end{array}$ \\
\hline $\begin{array}{l}\text { Intracoronary or } \\
\text { Intravenous Infusion } \\
\text { Human Wharton's } \\
\text { jelly-derived } \\
\text { Mesenchymal } \\
\text { Stromal Cells in } \\
\text { Patients With } \\
\text { Ischemic } \\
\text { Cardiomyopathy } \\
\text { (WJ-ICMP Tria) }\end{array}$ & NCT02368587 & $\begin{array}{l}\text { Evaluation of the } \\
\text { safety and efficacy of } \\
\text { MSC,WJ in patients } \\
\text { suffering from } \\
\text { ischemic } \\
\text { cardiomyopathy } \\
\text { secondary to MI }\end{array}$ & Estimated: 160 & $\begin{array}{l}\text { MSC,WJ infusion } \\
\text { or placebo }\end{array}$ & 2 & $\begin{array}{l}\text { Not yet } \\
\text { recruiting }\end{array}$ \\
\hline $\begin{array}{l}\text { Cardiovascular } \\
\text { Clinical Project to } \\
\text { Evaluate the } \\
\text { Regenerative } \\
\text { Capacity of } \\
\text { CardioCell in } \\
\text { Patients With Acute } \\
\text { Myocardial } \\
\text { Infarction (AMI) }\end{array}$ & NCT03404063 & $\begin{array}{c}\text { Stablish a } \\
\text { comparison of } \\
\text { outcomes between } \\
\text { patients suffering } \\
\text { from ischemic } \\
\text { damages treated with } \\
\text { CardioCell and a } \\
\text { control group (which } \\
\text { will be receiving } \\
\text { placebo) }\end{array}$ & 105 & $\begin{array}{c}\text { Active IMP } \\
\text { (known as } \\
\text { CardioCell) and } \\
\text { placebo }\end{array}$ & $2-3$ & Completed \\
\hline $\begin{array}{c}\text { WJMSCs } \\
\text { Anti-inflammatory } \\
\text { Therapy in Coronary } \\
\text { Artery Disease } \\
\text { (WANICHD) }\end{array}$ & NCT04551456 & $\begin{array}{l}\text { Evaluation of the } \\
\text { safety and } \\
\text { anti-inflammatory } \\
\text { efficacy of MSC,WJ } \\
\text { in patients with } \\
\text { coronary artery } \\
\text { atherosclerosis } \\
\text { disease }\end{array}$ & Estimated: 300 & $\begin{array}{l}\text { MSC,WJ infusion } \\
\text { or placebo }\end{array}$ & 2 & $\begin{array}{l}\text { Not yet } \\
\text { recruiting }\end{array}$ \\
\hline $\begin{array}{c}\text { WJMSCs } \\
\text { Anti-inflammatory } \\
\text { Therapy in Acute } \\
\text { Myocardial } \\
\text { Infarction (WAIAMI) }\end{array}$ & NCT04551443 & $\begin{array}{l}\text { Evaluation of the } \\
\text { safety and feasibility } \\
\text { of WJMSCs in the } \\
\text { treatment of patients } \\
\text { in the acute phase } \\
\text { (within } 24 \mathrm{~h} \text { ) with the } \\
\text { both of ST-Segment- } \\
\text { Elevation or } \\
\text { Non-ST-Segment- } \\
\text { Elevation } \\
\text { AMI. }\end{array}$ & Estimated: 200 & $\begin{array}{l}\text { MSC,WJ infusion } \\
\text { or placebo }\end{array}$ & & $\begin{array}{l}\text { Not yet } \\
\text { recruiting }\end{array}$ \\
\hline $\begin{array}{l}\text { Safety Evaluation of } \\
\text { Intracoronary } \\
\text { Infusion of } \\
\text { Extracellular Vesicles } \\
\text { in Patients With AMI }\end{array}$ & NCT04327635 & $\begin{array}{l}\text { Safety evaluation of } \\
\text { EVs in treating } \\
\text { patient with AMI }\end{array}$ & Estimated: 18 & $\begin{array}{c}\text { PEP drug (dosage } \\
\text { of } 5 \% ; 10 \% \text {; or } \\
20 \%)\end{array}$ & 1 & Recruiting \\
\hline
\end{tabular}




\subsection{PeriCord: A Valuable CASE in Scalability and GMP Biomanufacturing of Cardiac Bioimplants}

As previously mentioned, we explored the therapeutic potential of engineered cardiac bioimplants comprising cell-free cardiac scaffolds with preserved ECM structure and components aiming to deliver therapeutic MSC post-MI [66]. Remarkably, one of our two pre-clinically developed TE approaches has been scaled up to produce a clinical-size, good manufacturing practice (GMP)-compliant allogeneic ATMP. In specific, this novel ATMP is referred to as PeriCord and consists of $\sim 16 \mathrm{~cm}^{2}$ cardiac bioimplant comprising clinical-grade MSC,WJ (the active ingredient) within human decellularized pericardial ECM (acting as a cell supportive material to facilitate surgical implantation). The acceptance criteria for initial PeriCord batch certification comprises: (i) a dose range of 7-15 $\times 10^{6}$ total viable MSC,WJ; (ii) cell viability $\geq 70 \%$; and (iii) endotoxin $\leq 4$ units $/ \mathrm{mL}$ [50]. Safety data from PeriCord implantation are being evaluated in the ongoing phase I PERISCOPE (the PERIcardial matrix with mesenchymal Stem Cells fOr the treatment of PatiEnts with infarcted myocardial tissue) clinical trial (EudraCT No. 2018-001964-49; ClinicalTrials.gov (accessed on 30 June 2021) Id. NCT03798353) (Table 1). Importantly, eleven patients have already been recruite and no adverse effects directly related to the treatment have been observed to date.

In light of this clinical translation experience, we are currently taking further advantage of the window of opportunity that MSC-EV, instead of the MSC themselves, opens in terms of their plentiful cargo of molecules and associated functions, conserved morphology and integrity, and capacity of reaching either neighboring or distant cells and tissues upon administration. In particular, the rationale for the use of MSC-EV arises from the growing amount of data suggesting that these preparations are harmless and trigger, at least, similar effects to their parent cells. Moreover, MSC-EV are theoretically unaltered by microenvironmental factors due to their double-leaflet lipid membranes efficiently protect the inner molecular cargo from degradation and guarantee their entry into targeted cells. Additionally, their characteristic nanosize counteracts the potential risk of pulmonary thrombosis after intravascular administration of MSC due to the majority of infused cells are initially trapped in the lungs of recipients [67].

\section{Mesenchymal Stromal Cell-Secreted Extracellular Vesicles: The Envisioned Alternative}

In 1983, Stahl and collaborators reported that transferrin receptors were associated with small membranous vesicles that were actively expelled into the extracellular microenvironment by reticulocytes. This was one of the first descriptions of secreted cell-to-cell communication agents, which were later referred to as EV [68,69]. Notably, after nearly three decades of tremendous effort, EV are recognized as a wide diversity of lipid bilayerdelimited particles that are released by most cell types, including MSC. Succinctly, EV are distinctive in size, biogenesis, cargo molecules and function, and their classification is a major concern that remains controversial [70]. At present, EV are commonly divided into three categories according to size and formation pathway diversity as follows: (1) exosomes, which are intraluminal vesicular structures with a diameter ranging between 30 and $150 \mathrm{~nm}$ that are raised by the internal budding of the endosomal membrane during maturation of inner cellular multivesicular bodies (indeed, exosomes are increasingly designated "small EV"); (2) microvesicles that sprout directly from the plasma membrane and are released into the extracellular space, and have a wider size assortment than exosomes $(50 \mathrm{~nm}-1 \mu \mathrm{m})$; and (3) apoptotic bodies, varying from 1 to $5 \mu \mathrm{m}$ of diameter and externally released after an apoptotic cell disassembly procedure [71-73]. In an attempt to promote the standardization of EV characterisation, the International Society for Extracellular Vesicles (ISEV) proposed a set of "Minimal Information for Studies of Extracellular Vesicles" (or MISEV) guidelines for the field in 2014 and were recently updated in 2018 [73,74]. Indeed a better understanding of the composition of EV preparations may help to discern the actual biological activity of specific factors above the background. 
Regarding their composition, EV contain a wide variety of bioactive compounds such as RNA species (mainly miRNA), lipids, and cytosolic proteins and transmembrane proteins in an appropriate and functional formulation, resembling the content of the parental cells. This has prompted the investigation of EV as useful blood-based biomarkers for disease diagnosis and prognosis, pharmaceutic targets of diseases, and active ingredients in the context of novel advanced cell-free therapies against cardiovascular conditions $[10,75]$. The content and functional attributes of EV depend on different conditions, including cell viability status, stage of activation, infection, stress, and neoplastic transformation, among others. For instance, the presence (or absence) of specific serum components clearly affects $\mathrm{EV}$ biogenesis and characteristics as one of the wide range of molecular changes that cells undergo in response to cellular stress [76]. In 2005, Savina and collaborators described EV secretion as highly dependent on the calcium handling machinery of the parental cells [77]. In addition, exogenously-added substances such as silver nanoparticles into the culture cell medium seem to promote EV formation and secretion [78]. However, exosomes can be restricted in therapies preparation due to their difficulties incorporating the specific cargo [79]. Collectively, these findings indicate that cells behave differently under stress conditions and therefore this may have an impact on the potential traits of their secreted $\mathrm{EV}$, and point out the relevance of adjusting protocols for optimal cell culture conditions to guarantee the therapeutic efficacy of the resulting EV preparations.

Of note, EV may also act as an efficacious toolkit of cell-to-cell communication due to their ability to specifically modulate the molecular cargo and associated functions of targeted neighboring or distant cells or tissues [80]. In this regard, the protection conferred by these membranous nanovesicles to their internal effector molecules is crucial to warrant their triggered functions and governing MoA over time.

At the functional level, compelling pre-clinical studies show that MSC-EV are potent bioactive agents capable of modulating the host immune response, stimulating novel blood vessel formation (angiogenesis), cardioprotection (i.e., myocardial tissue injury reduction) and endothelial cell proliferation/migration, among other cardiovascular beneficial effects $[81,82]$. In brief, similar to the parental cells, EV have the potential to promote a shift in the pro-inflammatory milieu and functional changes in recipient immune cells, including monocytes/macrophages, dendritic cells, T cells, B cells and natural killer cells. In this context, the effect of MSC-EV on allogeneic T-cell stimulation and cytokine production in vitro has been found $[83,84]$. For instance, the addition of MSC-EV, such as those isolated from MSC,WJ using size-exclusion chromatography, was capable of powerfully preventing T-cell stimulation and reduced levels of adverse pro-inflammatory cytokine reaction [10].

In this context, MI and myocardial ischemia/reperfusion represent inflammationassociated diseases in which the immune-modulatory properties of MSC-EV could be of clinical relevance. Particularly, MI is accompanied by both exacerbated local and peripheral inflammatory responses, whereas myocardial ischemia/reperfusion triggers an over-activated inflammatory cascade in diseased hearts. However, in both conditions, the blockade of blood flow initiates an intense beneficial inflammatory effect that is essential for the early clearance of dead cells and subsequent cardiac repair and regeneration but, in turn, it becomes extremely deleterious if it is not timely suppressed. This leads to the post-infarction replacement of myocardial tissue by a non-contractile scar [85]. In this sense, MSC-EV seem to be valuable to modulate cardiac inflammation and improve overall cardiac functional parameters in failing hearts through distinct MoA that are currently under investigation. Numerous studies have shown that intramyocardial injection of MSC-EV from distinct tissue sources efficiently reduced the infarct size and enhances cardiac function preserving cardiac systolic and diastolic performance in ischemic rodent models [86-89]. In specific, it has been convincingly demonstrated that the benefit to macrophage polarization status is mediated by the miR-182 activity associated with MSC,WJ-secreted EV (MSC,WJ-EV) after their delivery in vivo [90]. In this same study of myocardial ischemia/reperfusion, intramyocardially injected MSC,WJ-EV also led to a remarkable reduction in infarct size and considerably alleviated undesirable inflammatory 
traits in both the heart and serum of EV-treated animals. Furthermore, engineered MSC-EV to overexpress miRNA-181a drastically influenced inflammatory response after myocardial ischemia-reperfusion injury, as demonstrated by Wei and collaborators [91]. These authors further confirmed that engineered MSC-EV led to a decrease in pro-inflammatory IL-6 and TNF- $\alpha$ levels, as well as an increase in anti-inflammatory cytokines such as IL-10 in injured mice. In order to allow these benefits, the mechanisms involved are considered multifactorial, since a joint action of antiapoptotic, anti-inflammatory and pro-survival effects happens [92].

In addition, administration of MSC-EV has shown to exert both protective and proregenerative effects against myocardial tissue damage provoked by acute MI, along with no risk of tumorigenicity and immune rejection after infusion [93].In fact, MSC-EV-driven cardio protection would include reduction in cardiomyocyte apoptosis and enhancement of cardiomyocyte viability post-MI. For instance, conditioned medium collected from cultured MSC and infused intravenously before reperfusion prompted a significant reduction in infarct size both in post-infarcted rodents and pigs [94]. Specifically, they concluded that benefit was reached by improved myocardial cell viability following in vivo treatment. This is in agreement with data from Arslan and collaborators, who observed that the administration of MSC-EV in mice resulted in increased ATP levels, decreased oxidative stress, and also triggered protective PI3K/Akt-mediated signaling in ischemic/reperfused hearts [95]. Furthermore MSC-EV delivery was capable of preventing cardiac muscle cells from apoptosis, and this cardioprotection was directly linked to specific miRNAs present in MSC-EV that specifically targeted the cell death regulation machinery [96,97]. Collectively, these studies are of paramount importance because they suggest increased improvements in myocardial tissue survival by MSC-EV and how this beneficial effect plays a key role in preventing subsequent adverse remodeling once myocardial ischemia/reperfusion injury is critically established.

In vivo administration of MSC-EV could promote active processes of myocardial angiogenesis in ischemic hearts due to the high levels of proangiogenic factors that MSCEV transfer locally. Following MSC-EV administration, EV-associated biomolecules trigger the proliferation and migration of endothelial-lineage progenitors or mature vascular cells. Hence, infarcted hearts treated with MSC-EV exhibited higher capillary densities compared to non-treated hearts within one month after myocardial/reperfusion injury $[87,88,98,99]$.

Currently, over one hundred clinical studies using EV are registered in the database www.clinicaltrials.gov (accessed on 17 August 2021). The majority of these studies evaluate endogenous EV as blood biomarkers for diagnostics rather than therapy. Despite the promising observations from the above-mentioned pre-clinical experience, the number of experimental treatments based on MSC-EV reaching the clinical stage is still very scarce in the context of MI to date. To the best of our knowledge, only one clinical trial, which is devoted to the safety evaluation of intracoronary infusion of MSC-EV in patients with acute MI (Table 1), has been posted so far, particularly by Mayo Clinic's investigators on 31 March 2020, without any patients recruited so far.

Nevertheless, we apperceive that this is also the right time to advance the design, development and clinical translation of cell-free ATMP based on biomanufactured MSC-EV (Figure 2). For that purpose, it will be crucial to further: (i) comprehend their specific MoA; (ii) establish optimal dosing and dosage; (iii) better evaluate their biodistribution and potential adverse effects; and (iv) adhere to GMP quality management guidelines and regulatory requirements. 


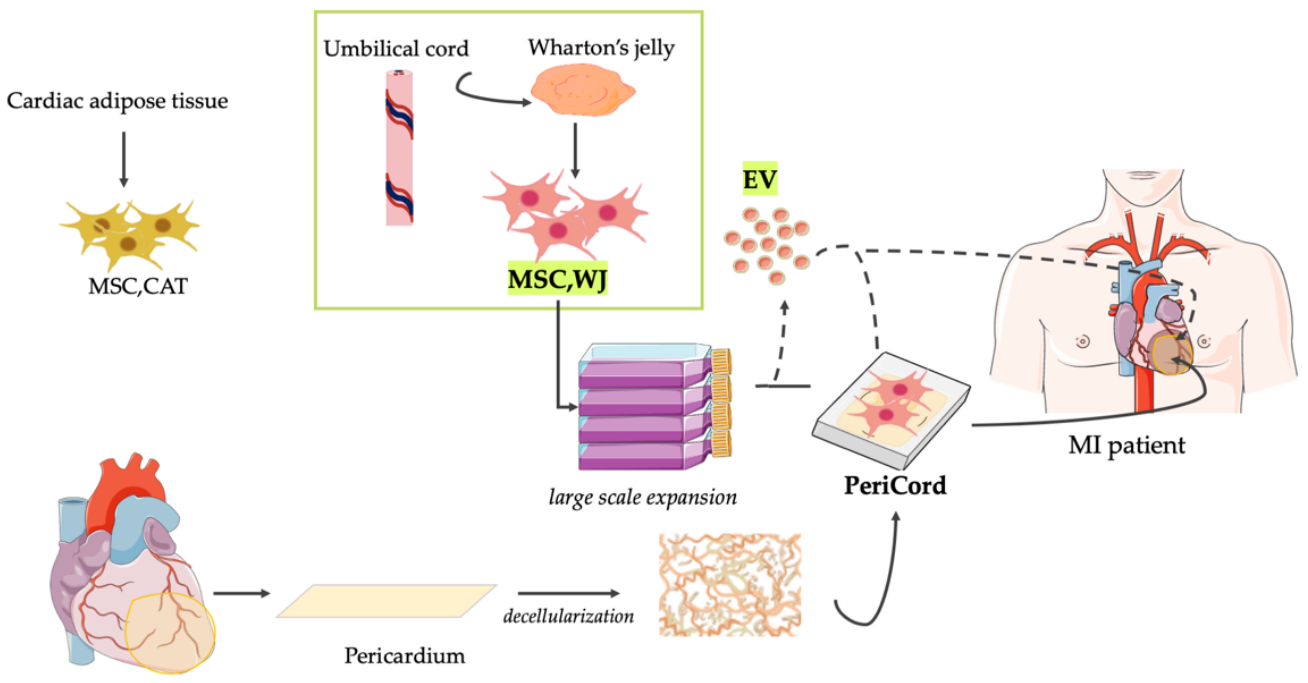

Figure 2. Current clinical translation of ATMP based on MSC and derived EV from Wharton's jelly. For years, our laboratories have actively collaborated in exploring innovative treatments for MI. Particularly, our pre-clinical evidencebased experience includes the study and application of a variety of cell therapy and TE approaches using MSC derived from cardiac adipose tissue (MSC,CAT) and Wharton's jelly (MSC,WJ). Recently, a clinical-size allogeneic cardiac bioimplant termed PeriCord has been implanted for limiting post-infarct sequelae in patients. As an alternative, the biomanufacturing and therapeutic use of novel ATMP based in MSC-EV resembling the characteristics of the parental MSC could be potentially adapted to the PeriCord production procedure. In fact, high yields of multifunctional EV with preserved function and purity could be isolated from the same large volume cultures of MSC,WJ prior to the generation of the PeriCord bioimplant. For that, however, progress in upcoming challenges, including good manufacturing practice and regulatory issues, will be crucial to demonstrate that this approach also holds potential for clinical translation. MSC,CAT = Cardiac Adipose Tissuederived Mesenchymal Stromal Cells; MSC,WJ = Wharton's jelly-derived Mesenchymal Stromal Cells; and EV = Extracellular Vesicles; MI = Myocardial Infarction.

\section{MSC-EV-Based Products: Clinical Perspectives and Biomanufacturing Challenges}

Cell-based TE therapies have gained interest in the field of regenerative medicine as promising approaches for the repair of post-infarcted myocardial tissue. This foundation is based, in part, on the improvements to efficiently collect sample preparations enriched with high amounts of paracrine multifunctional factors, including multifunctional nanovesicles found in the conditioned medium from culture-expandable MSC. Notably, MSC-EV can induce phenotypic and epigenetic changes in neighboring cells while traveling long distances to transfer their specific molecular cargoes to targeted cells or tissues and modulate biological processes accordingly. For this, the scientific community envisions the versatility and clinical potential of MSC-EV as innovative, cell-free, immunomodulatory, pro-regenerative therapy approach post-MI. EV confer many advantages over the parental MSC themselves, as they: (i) are non-replicative biological, and thus their administration evades potential risks of tumorigenesis; and (ii) exhibit stable characteristics, including shelf-life, permeability, biodistribution and toxicity, over time in either the autologous or allogeneic setting indistinctly.

Regarding the translation of MSC-EV products into the clinics, MSC-EV biomanufacturing requires specialized facilities, skilled personnel and sufficient financial resources to first produce high amounts of the parental cells and then purify their released EV consistently, from batch to batch, in compliance with GMP procedures. EV isolation methods are still complex and involve the use of equipment not designed for this purpose. This most probably explains why treatments based on MSC-EV are poorly present in the clinical scenario to date. Their clinical use relies on open/semi-open production systems which are labor-intensive, require manual processing, and represent high investment in building classified environments, equipment and training skilled staff. Current open/semi-open systems for MSC culturing are also potentially associated with considerable increasing costs, 
risk of contamination, great variability across batches, and lack of real-time in-process control. For this, there has been a tendency toward the introduction of more sophisticated automated platforms, including scalable bioreactor systems, which may simplify the biomanufacturing workflow and optimize resources. These platforms could highly impact on robustness, traceability and yields of clinical-grade MSC expansion, also reducing production costs and allowing a number of in-process controls providing more accurate predictions of compliance with final product specifications.

Moreover, to achieve successful translation of MSC-EV into useful therapy candidates, MSC-EV processing has to resolve major concerns from a biomanufacturing perspective, including standardized in-process quality controls, identification of bioactive components in the cargo of EVs and potency testing, as well as further progress in instrumentation for optimal EV quantification and dosage. In this regard, EV yields remain limiting due to conventional MSC culture or microenvironment conditions, including cell density, aging and passage, stage of differentiation and substrate topography, which considerably affect their intrinsic properties. In this sense, the use of bioreactors with high cell growth surface, media recirculation and repeated supernatant recovery appears highly valuable to fulfil current clinical standards or requirements. On the contrary, animal-derived growth supplements are discouraging for clinical-grade MSC and derivatives biomanufacturing because they can potentially induce adverse clinical effects once therapeutic products are administered. Most of these supplements have undergone limited characterization, and they might harbor potential animal pathogens that remain critically unknown. Alternative chemically-defined MSC culture media formulations need also to be immediately addressed in forthcoming MSC-EV applications.

Author Contributions: Conceptualization, J.V. and S.R.; methodology, N.M.-D., S.R., C.P.-V. and J.V.; formal analysis, N.M.-D., S.R., C.P.-V. and J.V.; writing-original draft preparation, N.M.-D., S.R., C.P.-V. and J.V.; writing-review and editing, N.M.-D., S.R., C.P.-V. and J.V.; funding acquisition, S.R., C.P.-V. and J.V. All authors have read and agreed to the published version of the manuscript.

Funding: This work has been developed in the context of ADVANCE(CAT) with the support of ACCIÓ (Catalonia Trade \& Investment; Generalitat de Catalunya) and the European Community under the Catalonian ERDF operational program (European Regional Development Fund) 2014-2020, Generalitat de Catalunya (Departament de Salut) PERIS Acció Instrumental de Programes de Recerca Orientats (SLT002/16/00234), Spanish Society of Cardiology, Catalan Society of Cardiology, Fundació bancària La Caixa, CIBER Cardiovascular (CB16/11/00403) and by the Spanish Cell Therapy Network (TerCel, expedient numbers: RD16/0011/0006 \& RD16/0011/0028). Projects PI19/01788, PI17/01487, PIC18/00014, ICI19/00039, PI18/00256, PI18/01227, ICI20/00135 are funded by Instituto de Salud Carlos III and co-funded by European Union (ERDF/ESF) - A way to build Europe. Projects SAF2017-84324-C2-1-R and PID2019-110137RB-I00 are funded the Spanish Ministry of Economy and Competitiveness-MICINN. Our laboratories are awarded by the Generalitat de Catalunya's AGAUR as Consolidated Research Groups (references 2017-SGR-483, 2017-SGR-719 and 2019PROD00122), and by the Catalan Heath Institute.

Institutional Review Board Statement: Not applicable.

Informed Consent Statement: Not applicable.

Conflicts of Interest: The authors declare no conflict of interest.

\section{References}

1. World Health Organization (WHO). The Top 10 Causes of Death. 24 Maggio. 2018. Available online: http://www.who.int/en/ news-room/fact-sheets/detail/the-top-10-causes-of-death (accessed on 17 August 2020).

2. World Health Organization (WHO). Cardiovascular Diseases (CVDs). 2017. Available online: https://www.who.int/newsroom/fact-sheets / detail/ cardiovascular-diseases-(cvds) (accessed on 24 November 2020).

3. Katz, J.; Waters, S.; Hollis, I.; Chang, P. Advanced Therapies For End-Stage Heart Failure. Curr. Cardiol. Rev. 2014, 11, 63-72. [CrossRef]

4. Dzobo, K.; Thomford, N.E.; Senthebane, D.A.; Shipanga, H.; Rowe, A.; Dandara, C.; Pillay, M.; Shirley, K.; Motaung, C.M. Innovation and Transformation of Medicine. Stem Cells Int. 2018, 2018, 24. [CrossRef] 
5. Potena, L.; Zuckermann, A.; Barberini, F.; Aliabadi-Zuckermann, A. Complications of Cardiac Transplantation. Curr. Cardiol. Rep. 2018, 20, 73. [CrossRef]

6. Roura, S.; Gálvez-Montón, C.; Mirabel, C.; Vives, J.; Bayes-Genis, A. Mesenchymal stem cells for cardiac repair: Are the actors ready for the clinical scenario? Stem Cell Res. Ther. 2017, 8, 238. [CrossRef]

7. Gyöngyösi, M.; Haller, P.M.; Blake, D.J.; Martin Rendon, E. Meta-Analysis of Cell Therapy Studies in Heart Failure and Acute Myocardial Infarction. Circ. Res. 2018, 123, 301-308. [CrossRef]

8. Menasché, P.; Vanneaux, V.; Hagège, A.; Bel, A.; Cholley, B.; Parouchev, A.; Cacciapuoti, I.; Al-Daccak, R.; Benhamouda, N.; Blons, H.; et al. Transplantation of Human Embryonic Stem Cell-Derived Cardiovascular Progenitors for Severe Ischemic Left Ventricular Dysfunction. J. Am. Coll. Cardiol. 2018, 71, 429-438. [CrossRef]

9. Yang, L.; Zhu, J.; Zhang, C.; Wang, J.; Yue, F.; Jia, X.; Liu, H. Stem cell-derived extracellular vesicles for myocardial infarction: A meta-analysis of controlled animal studies. Aging 2019, 11, 1129-1150. [CrossRef]

10. Monguió-Tortajada, M.; Roura, S.; Gálvez-Montón, C.; Pujal, J.M.; Aran, G.; Sanjurjo, L.; Franquesa, M.; Sarrias, M.-R.; BayesGenis, A.; Borràs, F.E. Nanosized UCMSC-derived extracellular vesicles but not conditioned medium exclusively inhibit the inflammatory response of stimulated T cells: Implications for nanomedicine. Theranostics 2017, 7, 270-284. [CrossRef]

11. García-Muñoz, E.; Vives, J. Towards the standardization of methods of tissue processing for the isolation of mesenchymal stromal cells for clinical use. Cytotechnology 2021, 73, 1-10. [CrossRef]

12. Nombela-Arrieta, C.; Ritz, J.; Silberstein, L.E. The elusive nature and function of mesenchymal stem cells. Nat. Rev. Mol. Cell Biol. 2011, 12, 126-131. [CrossRef]

13. Dominici, M.; Le Blanc, K.; Mueller, I.; Slaper-Cortenbach, I.; Marini, F.C.; Krause, D.S.; Deans, R.J.; Keating, A.; Prockop, D.J.; Horwitz, E.M. Minimal criteria for defining multipotent mesenchymal stromal cells. The International Society for Cellular Therapy position statement. Cytotherapy 2006, 8, 315-317. [CrossRef] [PubMed]

14. Lalu, M.M.; McIntyre, L.; Pugliese, C.; Fergusson, D.; Winston, B.W.; Marshall, J.C.; Granton, J.; Stewart, D.J. Safety of cell therapy with mesenchymal stromal cells (SafeCell): A systematic review and meta-analysis of clinical trials. PLoS ONE 2012, 7, e47559. [CrossRef]

15. Lalu, M.M.; Mazzarello, S.; Zlepnig, J.; Dong, Y.Y.R.; Montroy, J.; McIntyre, L.; Devereaux, P.J.; Stewart, D.J.; David Mazer, C.; Barron, C.C.; et al. Safety and Efficacy of Adult Stem Cell Therapy for Acute Myocardial Infarction and Ischemic Heart Failure (SafeCell Heart): A Systematic Review and Meta-Analysis. Stem Cells Transl. Med. 2018, 7, 857-866. [CrossRef] [PubMed]

16. García-Fernández, C.; López-Fernández, A.; Borrós, S.; Lecina, M.; Vives, J. Strategies for large-scale expansion of clinical-grade human multipotent mesenchymal stromal cells. Biochem. Eng. J. 2020, 159, 107601. [CrossRef]

17. Thompson, M.; Mei, S.H.J.; Wolfe, D.; Champagne, J.; Fergusson, D.; Stewart, D.J.; Sullivan, K.J.; Doxtator, E.; Lalu, M.; English, S.W.; et al. Cell therapy with intravascular administration of mesenchymal stromal cells continues to appear safe: An updated systematic review and meta-analysis. EClinicalMedicine 2020, 19. [CrossRef]

18. Prockop, D.J. The exciting prospects of new therapies with mesenchymal stromal cells. Cytotherapy 2017, 19, 1-8. [CrossRef]

19. Reis, M.; Ogonek, J.; Qesari, M.; Borges, N.M.; Nicholson, L.; Preußner, L.; Dickinson, A.M.; Wang, X.; Weissinger, E.M.; Richter, A. Recent developments in cellular immunotherapy for HSCT-associated complications. Front. Immunol. 2016, 7. [CrossRef]

20. Kidd, S.; Spaeth, E.; Dembinski, J.L.; Dietrich, M.; Watson, K.; Klopp, A.; Battula, V.L.; Weil, M.; Andreeff, M.; Marini, F.C. Direct evidence of mesenchymal stem cell tropism for tumor and wounding microenvironments using in vivo bioluminescent imaging. Stem Cells 2009, 27, 2614-2623. [CrossRef]

21. Vives, J.; Casademont-Roca, A.; Martorell, L.; Nogués, N. Beyond chimerism analysis: Methods for tracking a new generation of cell-based medicines. Bone Marrow Transpl. 2020, 55, 1229-1239. [CrossRef]

22. Galleu, A.; Riffo-Vasquez, Y.; Trento, C.; Lomas, C.; Dolcetti, L.; Cheung, T.S.; Von Bonin, M.; Barbieri, L.; Halai, K.; Ward, S.; et al. Apoptosis in mesenchymal stromal cells induces in vivo recipient-mediated immunomodulation. Sci. Transl. Med. 2017, 9. [CrossRef]

23. Perea-Gil, I.; Monguió-Tortajada, M.; Gálvez-Montón, C.; Bayes-Genis, A.; Borràs, F.E.; Roura, S. Preclinical evaluation of the immunomodulatory properties of cardiac adipose tissue progenitor cells using umbilical cord blood mesenchymal stem cells: A direct comparative study. BioMed Res. Int. 2015, 2015. [CrossRef]

24. Gruhn, B.; Brodt, G.; Ernst, J. Extended Treatment With Mesenchymal Stromal Cells-Frankfurt am Main (MSC-FFM, Obnitix) in a Pediatric Patient With Steroid-refractory Acute Gastrointestinal Graft-Versus-Host Disease (GVHD): Case Report and Review of the Literature. J. Pediatr. Hematol. Oncol. 2021, 43, e419-e425. [CrossRef] [PubMed]

25. Bonig, H.; Kuçi, Z.; Kuçi, S.; Bakhtiar, S.; Basu, O.; Bug, G.; Dennis, M.; Greil, J.; Barta, A.; Kállay, K.M.; et al. Children and Adults with Refractory Acute Graft-versus-Host Disease Respond to Treatment with the Mesenchymal Stromal Cell Preparation "MSC-FFM"-Outcome Report of 92 Patients. Cells 2019, 8, 1577. [CrossRef] [PubMed]

26. Le Blanc, K.; Frassoni, F.; Ball, L.; Locatelli, F.; Roelofs, H.; Lewis, I.; Lanino, E.; Sundberg, B.; Bernardo, M.E.; Remberger, M.; et al. Mesenchymal stem cells for treatment of steroid-resistant, severe, acute graft-versus-host disease: A phase II study. Lancet 2008, 371, 1579-1586. [CrossRef]

27. Alvarez-Palomo, B.; Vives, J.; Casaroli-Marano, R.P.; Gomez, S.G.; Rodriguez Gómez, L.; Edel, M.; Querol Giner, S. Adapting Cord Blood Collection and Banking Standard Operating Procedures for HLA-Homozygous Induced Pluripotent Stem Cells Production and Banking for Clinical Application. J. Clin. Med. 2019, 8, 476. [CrossRef] [PubMed] 
28. Oliver-Vila, I.; Coca, M.I.; Grau-Vorster, M.; Pujals-Fonts, N.; Caminal, M.; Casamayor-Genescà, A.; Ortega, I.; Reales, L.; Pla, A.; Blanco, M.; et al. Evaluation of a cell-banking strategy for the production of clinical grade mesenchymal stromal cells from Wharton's jelly. Cytotherapy 2016, 18, 25-35. [CrossRef]

29. Ramallo, M.; Carreras-Sánchez, I.; López-Fernández, A.; Vélez, R.; Aguirre, M.; Feldman, S.; Vives, J. Advances in translational orthopaedic research with species-specific multipotent mesenchymal stromal cells derived from the umbilical cord. Histol. Histopathol. 2020, 18249. [CrossRef]

30. Martensen, R. Thomas Wharton's Adenographia (review). Bull. Hist. Med. 1998, 72, 762-763. [CrossRef]

31. McElreavey, K.D.; Irvine, A.I.; Ennis, K.T.; McLean, W.H.I. Isolation, culture and characterisation of fibroblast-like cells derived from the Wharton's jelly portion of human umbilical cord. Biochem. Soc. Trans. 1991, 19, 29S. [CrossRef]

32. Grau-vorster, M.; Laitinen, A.; Nystedt, J.; Vives, J. HLA-DR expression in clinical-grade bone marrow-derived multipotent mesenchymal stromal cells: A two-site study. Stem Cell Res. Ther. 2019, 9, 1-8. [CrossRef]

33. Grau-Vorster, M.; Rodríguez, L.; Torrents-Zapata, S.; Vivas, D.; Codinach, M.; Blanco, M.; Oliver-Vila, I.; García-López, J.; Vives, J. Levels of IL-17F and IL-33 correlate with HLA-DR activation in clinical-grade human bone marrow-derived multipotent mesenchymal stromal cell expansion cultures. Cytotherapy 2019, 21, 32-40. [CrossRef] [PubMed]

34. Grau-Vorster, M.; Rodríguez, L.; del Mazo-Barbara, A.; Mirabel, C.; Blanco, M.; Codinach, M.; Gómez, S.G.; Querol, S.; GarcíaLópez, J.; Vives, J. Compliance with Good Manufacturing Practice in the Assessment of Immunomodulation Potential of Clinical Grade Multipotent Mesenchymal Stromal Cells Derived from Wharton's Jelly. Cells 2019, 8, 484. [CrossRef] [PubMed]

35. Deuse, T.; Stubbendorff, M.; Tang-Quan, K.; Phillips, N.; Kay, M.A.; Eiermann, T.; Phan, T.T.; Volk, H.D.; Reichenspurner, H.; Robbins, R.C.; et al. Immunogenicity and immunomodulatory properties of umbilical cord lining mesenchymal stem cells. Cell Transplant. 2011, 20, 655-667. [CrossRef]

36. Garcia-lopez, J.; Delgadillo, J.; Vilarrodona, A.; Querol, S.; Ovejo, J.; Vives, J.; Herrero, M.J.; Lopez, I.; Sauleda, S.; Contreras, E. SARS-Cov-2/COVID-19 pandemic: First wave, impact, response and lessons learnt in a fully integrated Regional Blood and Tissue Bank. A narrative report. Blood Transfus. 2020, 1-10. [CrossRef]

37. Albu, S.; Kumru, H.; Coll, R.; Vives, J.; Vallés, M.; Benito-Penalva, J.; Rodríguez, L.; Codinach, M.; Hernández, J.; Navarro, X.; et al. Clinical effects of intrathecal administration of expanded Wharton jelly mesenchymal stromal cells in patients with chronic complete spinal cord injury: A randomized controlled study. Cytotherapy 2021, 23, 146-156. [CrossRef]

38. Gálvez-Montón, C.; Prat-Vidal, C.; Roura, S.; Soler-Botija, C.; Bayes-Genis, A. Update: Innovation in cardiology (IV). Cardiac tissue engineering and the bioartificial heart. Rev. Esp. Cardiol. 2013, 66, 391-399. [CrossRef] [PubMed]

39. Hirt, M.N.; Hansen, A.; Eschenhagen, T. Cardiac tissue engineering: State of the art. Circ. Res. 2014, 114, 354-367. [CrossRef]

40. Sarig, U.; Machluf, M. Engineering cell platforms for myocardial regeneration. Expert Opin. Biol. Ther. 2011, 11, 1055-1077. [CrossRef]

41. Perea-Gil, I.; Prat-Vidal, C.; Bayes-Genis, A. In vivo experience with natural scaffolds for myocardial infarction: The times they are a-changin'. Stem Cell Res. Ther. 2015, 6. [CrossRef]

42. Ott, H.C.; Matthiesen, T.S.; Goh, S.; Black, L.D.; Kren, S.M.; Netoff, T.I.; Taylor, D.A. Perfusion-decellularized matrix: Using nature's platform to engineer a bioartificial heart. Nat. Med. 2008, 14, 213-221. [CrossRef]

43. Gálvez-Montón, C.; Fernandez-Figueras, M.T.; Martí, M.; Soler-Botija, C.; Roura, S.; Perea-Gil, I.; Prat-Vidal, C.; Llucià-Valldeperas, A.; Raya, Á.; Bayes-Genis, A. Neoinnervation and neovascularization of acellular pericardial-derived scaffolds in myocardial infarcts. Stem Cell Res. Ther. 2015, 6. [CrossRef]

44. Seif-Naraghi, S.B.; Singelyn, J.M.; Salvatore, M.A.; Osborn, K.G.; Wang, J.J.; Sampat, U.; Kwan, O.L.; Strachan, G.M.; Wong, J.; Schup-Magoffin, P.J.; et al. Safety and efficacy of an injectable extracellular matrix hydrogel for treating myocardial infarction. Sci. Transl. Med. 2013, 5, 173ra25. [CrossRef]

45. Loh, Q.L.; Choong, C. Three-dimensional scaffolds for tissue engineering applications: Role of porosity and pore size. Tissue Eng. Part B Rev. 2013, 19, 485-502. [CrossRef]

46. Prat-Vidal, C.; Gálvez-Montón, C.; Puig-Sanvicens, V.; Sanchez, B.; Díaz-Güemes, I.; Bogónez-Franco, P.; Perea-Gil, I.; Casas-Solà, A.; Roura, S.; Llucià-Valldeperas, A.; et al. Online monitoring of myocardial bioprosthesis for cardiac repair. Int. J. Cardiol. 2014, 174, 654-661. [CrossRef] [PubMed]

47. Perea-Gil, I.; Uriarte, J.J.; Prat-Vidal, C.; Gálvez-Montón, C.; Roura, S.; Llucià-Valldeperas, A.; Soler-Botija, C.; Farré, R.; Navajas, D.; Bayes-Genis, A. In vitro comparative study of two decellularization protocols in search of an optimal myocardial scaffold for recellularization. Am. J. Transl. Res. 2015, 7, 558-573. [PubMed]

48. Prat-Vidal, C.; Bayes-Genis, A. Decellularized pericardial extracellular matrix: The preferred porous scaffold for regenerative medicine. Xenotransplantation 2020, 27, e12580. [CrossRef]

49. Perea-Gil, I.; Gálvez-Montón, C.; Prat-Vidal, C.; Jorba, I.; Segú-Vergés, C.; Roura, S.; Soler-Botija, C.; Iborra-Egea, O.; RevueltaLópez, E.; Fernández, M.A.; et al. Head-to-head comparison of two engineered cardiac grafts for myocardial repair: From scaffold characterization to pre-clinical testing. Sci. Rep. 2018, 8, 6708. [CrossRef]

50. Prat-Vidal, C.; Rodríguez-Gómez, L.; Aylagas, M.; Nieto-Nicolau, N.; Gastelurrutia, P.; Agustí, E.; Gálvez-Montón, C.; Jorba, I.; Teis, A.; Monguió-Tortajada, M.; et al. First-in-human PeriCord cardiac bioimplant: Scalability and GMP manufacturing of an allogeneic engineered tissue graft. EBioMedicine 2020, 54, 102729. [CrossRef] 
51. Gálvez-Montón, C.; Bragós, R.; Soler-Botija, C.; Díaz-Güemes, I.; Prat-Vidal, C.; Crisóstomo, V.; Sánchez-Margallo, F.M.; LluciàValldeperas, A.; Bogónez-Franco, P.; Perea-Gil, I.; et al. Noninvasive Assessment of an Engineered Bioactive Graft in Myocardial Infarction: Impact on Cardiac Function and Scar Healing. Stem Cells Transl. Med. 2017, 6, 647-655. [CrossRef] [PubMed]

52. Ye, L.; Chang, Y.H.; Xiong, Q.; Zhang, P.; Zhang, L.; Somasundaram, P.; Lepley, M.; Swingen, C.; Su, L.; Wendel, J.S.; et al. Cardiac repair in a porcine model of acute myocardial infarction with human induced pluripotent stem cell-derived cardiovascular cells. Cell Stem Cell 2014, 15, 750-761. [CrossRef]

53. Dixon, J.A.; Gorman, R.C.; Stroud, R.E.; Mukherjee, R.; Meyer, E.C.; Baker, N.L.; Morita, M.; Hamamoto, H.; Ryan, L.P.; Gorman 3rd, J.H.; et al. Targeted regional injection of biocomposite microspheres alters post-myocardial infarction remodeling and matrix proteolytic pathways. Circulation 2011, 124, S35-S45. [CrossRef]

54. Perea-Gil, I.; Prat-Vidal, C.; Gálvez-Montón, C.; Roura, S.; Llucià-Valldeperas, A.; Soler-Botija, C.; Iborra-Egea, O.; Díaz-Güemes, I.; Crisóstomo, V.; Sánchez-Margallo, F.M.; et al. A Cell-Enriched Engineered Myocardial Graft Limits Infarct Size and Improves Cardiac Function: Pre-Clinical Study in the Porcine Myocardial Infarction Model. JACC Basic Transl. Sci. 2016, 1, 360-372. [CrossRef] [PubMed]

55. Araña, M.; Gavira, J.J.; Peña, E.; González, A.; Abizanda, G.; Cilla, M.; Pérez, M.M.; Albiasu, E.; Aguado, N.; Casado, M.; et al. Epicardial delivery of collagen patches with adipose-derived stem cells in rat and minipig models of chronic myocardial infarction. Biomaterials 2014, 35, 143-151. [CrossRef]

56. Yu, L.H.; Kim, M.H.; Park, T.H.; Cha, K.S.; Kim, Y.D.; Quan, M.L.; Rho, M.S.; Seo, S.Y.; Jung, J.S. Improvement of cardiac function and remodeling by transplanting adipose tissue-derived stromal cells into a mouse model of acute myocardial infarction. Int. J. Cardiol. 2010, 139, 166-172. [CrossRef] [PubMed]

57. Doppler, S.A.; Deutsch, M.-A.; Lange, R.; Krane, M. Cardiac regeneration: Current therapies-future concepts. J. Thorac. Dis. 2013, 5, 683-697. [CrossRef] [PubMed]

58. Hoke, N.N.; Salloum, F.N.; Loesser-Casey, K.E.; Kukreja, R.C. Cardiac regenerative potential of adipose tissue-derived stem cells. Acta Physiol. Hung. 2009, 96, 251-265. [CrossRef]

59. Roura, S.; Bagó, J.R.; Soler-Botija, C.; Pujal, J.M.; Gálvez-Montón, C.; Prat-Vidal, C.; Llucià-Valldeperas, A.; Blanco, J.; Bayes-Genis, A. Human umbilical cord blood-derived mesenchymal stem cells promote vascular growth in vivo. PLoS ONE 2012, 7, e49447. [CrossRef]

60. Roura, S.; Soler-Botija, C.; Bagó, J.R.; Llucià-Valldeperas, A.; Férnandez, M.A.; Gálvez-Montón, C.; Prat-Vidal, C.; Perea-Gil, I.; Blanco, J.; Bayes-Genis, A. Postinfarction Functional Recovery Driven by a Three-Dimensional Engineered Fibrin Patch Composed of Human Umbilical Cord Blood-Derived Mesenchymal Stem Cells. Stem Cells Transl. Med. 2015, 4, 956-966. [CrossRef]

61. Aguilar, E.; Bagó, J.R.; Soler-Botija, C.; Alieva, M.; Rigola, M.A.; Fuster, C.; Vila, O.F.; Rubio, N.; Blanco, J. Fast-proliferating adipose tissue mesenchymal-stromal-like cells for therapy. Stem Cells Dev. 2014, 23, 2908-2920. [CrossRef]

62. Soler-Botija, C.; Bagó, J.R.; Llucià-Valldeperas, A.; Vallés-Lluch, A.; Castells-Sala, C.; Martínez-Ramos, C.; Fernández-Muiños, T.; Chachques, J.C.; Pradas, M.M.; Semino, C.E.; et al. Engineered 3D bioimplants using elastomeric scaffold, self-assembling peptide hydrogel, and adipose tissue-derived progenitor cells for cardiac regeneration. Am. J. Transl. Res. 2014, 6, $291-301$.

63. Bagó, J.R.; Soler-Botija, C.; Casaní, L.; Aguilar, E.; Alieva, M.; Rubio, N.; Bayes-Genis, A.; Blanco, J. Bioluminescence imaging of cardiomyogenic and vascular differentiation of cardiac and subcutaneous adipose tissue-derived progenitor cells in fibrin patches in a myocardium infarct model. Int. J. Cardiol. 2013, 169, 288-295. [CrossRef]

64. Gastelurrutia, P.; Prat-Vidal, C.; Vives, J. Transitioning from preclinical evidence to advanced therapy medicinal product: A Spanish experience. Front. Cardiovasc. Med. Press 2021. [CrossRef]

65. Gao, L.R.; Chen, Y.; Zhang, N.K.; Yang, X.L.; Liu, H.L.; Wang, Z.G.; Yan, X.Y.; Wang, Y.; Zhu, Z.M.; Li, T.C.; et al. Intracoronary infusion of Wharton's jelly-derived mesenchymal stem cells in acute myocardial infarction: Double-blind, randomized controlled trial. BMC Med. 2015, 13, 1-15. [CrossRef] [PubMed]

66. Roura, S.; Monguió-Tortajada, M.; Prat-Vidal, C.; Gálvez-Montón, C.; Bayes-Genis, A. Our Journey Through Advanced Therapies to Reduce Post-Infarct Scarring. Stem Cell Rev. Rep. 2021. [CrossRef] [PubMed]

67. Coppin, L.; Sokal, E.; Stéphenne, X. Thrombogenic Risk Induced by Intravascular Mesenchymal Stem Cell Therapy: Current Status and Future Perspectives. Cells 2019, 8, 1160. [CrossRef]

68. Harding, C.; Heuser, J.; Stahl, P. Receptor-mediated endocytosis of transferrin and recycling of the transferrin receptor in rat reticulocytes. J. Cell Biol. 1983, 97, 329-339. [CrossRef] [PubMed]

69. Harding, C.; Heuser, J.; Stahl, P. Endocytosis and intracellular processing of transferrin and colloidal gold-transferrin in rat reticulocytes: Demonstration of a pathway for receptor shedding. Eur. J. Cell Biol. 1984, 35, 256-263.

70. Gould, S.J.; Raposo, G. As we wait: Coping with an imperfect nomenclature for extracellular vesicles. J. Extracell. Vesicles 2013, 2. [CrossRef]

71. Poon, I.K.H.; Parkes, M.A.F.; Jiang, L.; Atkin-Smith, G.K.; Tixeira, R.; Gregory, C.D.; Ozkocak, D.C.; Rutter, S.F.; Caruso, S.; Santavanond, J.P.; et al. Moving beyond size and phosphatidylserine exposure: Evidence for a diversity of apoptotic cell-derived extracellular vesicles in vitro. J. Extracell. Vesicles 2019, 8, 1608786. [CrossRef]

72. Tricarico, C.; Clancy, J.; D’Souza-Schorey, C. Biology and biogenesis of shed microvesicles. Small GTPases 2017, 8, $220-232$. [CrossRef] 
73. Lötvall, J.; Hill, A.F.; Hochberg, F.; Buzás, E.I.; Di Vizio, D.; Gardiner, C.; Gho, Y.S.; Kurochkin, I.V.; Mathivanan, S.; Quesenberry, P.; et al. Minimal experimental requirements for definition of extracellular vesicles and their functions: A position statement from the International Society for Extracellular Vesicles. J. Extracell. Vesicles 2014, 3, 26913. [CrossRef]

74. Théry, C.; Witwer, K.W.; Aikawa, E.; Alcaraz, M.J.; Anderson, J.D.; Andriantsitohaina, R.; Antoniou, A.; Arab, T.; Archer, F.; Atkin-Smith, G.K.; et al. Minimal information for studies of extracellular vesicles 2018 (MISEV2018): A position statement of the International Society for Extracellular Vesicles and update of the MISEV2014 guidelines. J. Extracell. Vesicles 2018, 7, 1535750. [CrossRef] [PubMed]

75. Bagno, L.; Hatzistergos, K.E.; Balkan, W.; Hare, J.M. Mesenchymal Stem Cell-Based Therapy for Cardiovascular Disease: Progress and Challenges. Mol. Ther. 2018, 26, 1610-1623. [CrossRef]

76. Lund, P.; Pilgaard, L.; Duroux, M.; Fink, T.; Zachar, V. Effect of growth media and serum replacements on the proliferation and differentiation of adipose-derived stem cells. Cytotherapy 2009, 11, 189-197. [CrossRef] [PubMed]

77. Savina, A.; Fader, C.M.; Damiani, M.T.; Colombo, M.I. Rab11 promotes docking and fusion of multivesicular bodies in a calcium-dependent manner. Traffic 2005, 6, 131-143. [CrossRef]

78. Gurunathan, S.; Kang, M.; Jeyaraj, M.; Qasim, M.; Kim, J. Function, and Multifarious Therapeutic Approaches of Exosomes. Cells 2019, 8, 307. [CrossRef] [PubMed]

79. Klyachko, N.L.; Arzt, C.J.; Li, S.M.; Gololobova, O.A.; Batrakova, E.V. Extracellular Vesicle-Based Therapeutics: Preclinical and Clinical Investigations. Pharmaceutics 2020, 12, 1171. [CrossRef]

80. Yáñez-Mó, M.; Siljander, P.R.-M.; Andreu, Z.; Zavec, A.B.; Borràs, F.E.; Buzas, E.I.; Buzas, K.; Casal, E.; Cappello, F.; Carvalho, J.; et al. Biological properties of extracellular vesicles and their physiological functions. J. Extracell. Vesicles 2015, 4, 27066. [CrossRef]

81. Baek, G.; Choi, H.; Kim, Y.; Lee, H.-C.; Choi, C. Mesenchymal Stem Cell-Derived Extracellular Vesicles as Therapeutics and as a Drug Delivery Platform. Stem Cells Transl. Med. 2019, 8, 880-886. [CrossRef]

82. Yi, Y.W.; Lee, J.H.; Kim, S.-Y.; Pack, C.-G.; Ha, D.H.; Park, S.R.; Youn, J.; Cho, B.S. Advances in Analysis of Biodistribution of Exosomes by Molecular Imaging. Int. J. Mol. Sci. 2020, 21, 665. [CrossRef]

83. van den Akker, F.; Vrijsen, K.R.; Deddens, J.C.; Buikema, J.W.; Mokry, M.; van Laake, L.W.; Doevendans, P.A.; Sluijter, J.P.G Suppression of $\mathrm{T}$ cells by mesenchymal and cardiac progenitor cells is partly mediated via extracellular vesicles. Heliyon 2018, 4 , e00642. [CrossRef] [PubMed]

84. Blazquez, R.; Sanchez-Margallo, F.M.; de la Rosa, O.; Dalemans, W.; Alvarez, V.; Tarazona, R.; Casado, J.G. Immunomodulatory Potential of Human Adipose Mesenchymal Stem Cells Derived Exosomes on in vitro Stimulated T Cells. Front. Immunol. 2014, 5, 556. [CrossRef] [PubMed]

85. Frangogiannis, N.G. The inflammatory response in myocardial injury, repair, and remodelling. Nat. Rev. Cardiol. 2014, 11, 255-265. [CrossRef]

86. Teng, X.; Chen, L.; Chen, W.; Yang, J.; Yang, Z.; Shen, Z. Mesenchymal Stem Cell-Derived Exosomes Improve the Microenvironment of Infarcted Myocardium Contributing to Angiogenesis and Anti-Inflammation. Cell. Physiol. Biochem. 2015, 37, 2415-2424. [CrossRef] [PubMed]

87. Bian, S.; Zhang, L.; Duan, L.; Wang, X.; Min, Y.; Yu, H. Extracellular vesicles derived from human bone marrow mesenchymal stem cells promote angiogenesis in a rat myocardial infarction model. J. Mol. Med. 2014, 92, 387-397. [CrossRef] [PubMed]

88. Ju, C.; Shen, Y.; Ma, G.; Liu, Y.; Cai, J.; Kim, I.-M.; Weintraub, N.L.; Liu, N.; Tang, Y. Transplantation of Cardiac Mesenchymal Stem Cell-Derived Exosomes Promotes Repair in Ischemic Myocardium. J. Cardiovasc. Transl. Res. 2018, 11, 420-428. [CrossRef]

89. Kang, K.; Ma, R.; Cai, W.; Huang, W.; Paul, C.; Liang, J.; Wang, Y.; Zhao, T.; Kim, H.W.; Xu, M.; et al. Exosomes Secreted from CXCR4 Overexpressing Mesenchymal Stem Cells Promote Cardioprotection via Akt Signaling Pathway following Myocardial Infarction. Stem Cells Int. 2015, 2015, 659890. [CrossRef]

90. Zhao, J.; Li, X.; Hu, J.; Chen, F.; Qiao, S.; Sun, X.; Gao, L.; Xie, J.; Xu, B. Mesenchymal stromal cell-derived exosomes attenuate myocardial ischaemia-reperfusion injury through miR-182-regulated macrophage polarization. Cardiovasc. Res. 2019, 115, 1205-1216. [CrossRef]

91. Wei, Z.; Qiao, S.; Zhao, J.; Liu, Y.; Li, Q.; Wei, Z.; Dai, Q.; Kang, L.; Xu, B. miRNA-181a over-expression in mesenchymal stem cell-derived exosomes influenced inflammatory response after myocardial ischemia-reperfusion injury. Life Sci. 2019, $232,116632$. [CrossRef]

92. Riaud, M.; Martinez, M.C.; Montero-Menei, C.N. Scaffolds and Extracellular Vesicles as a Promising Approach for Cardiac Regeneration after Myocardial Infarction. Pharmaceutics 2020, 12, 1195. [CrossRef]

93. Sun, S.-J.; Wei, R.; Li, F.; Liao, S.-Y.; Tse, H.-F. Mesenchymal stromal cell-derived exosomes in cardiac regeneration and repair. Stem Cell Rep. 2021. [CrossRef]

94. Lai, R.C.; Arslan, F.; Lee, M.M.; Sze, N.S.K.; Choo, A.; Chen, T.S.; Salto-Tellez, M.; Timmers, L.; Lee, C.N.; El Oakley, R.M.; et al. Exosome secreted by MSC reduces myocardial ischemia/reperfusion injury. Stem Cell Res. 2010, 4, 214-222. [CrossRef]

95. Arslan, F.; Lai, R.C.; Smeets, M.B.; Akeroyd, L.; Choo, A.; Aguor, E.N.E.; Timmers, L.; van Rijen, H.V.; Doevendans, P.A.; Pasterkamp, G.; et al. Mesenchymal stem cell-derived exosomes increase ATP levels, decrease oxidative stress and activate PI3K/Akt pathway to enhance myocardial viability and prevent adverse remodeling after myocardial ischemia/reperfusion injury. Stem Cell Res. 2013, 10, 301-312. [CrossRef] 
96. Wang, X.; Gu, H.; Qin, D.; Yang, L.; Huang, W.; Essandoh, K.; Wang, Y.; Caldwell, C.C.; Peng, T.; Zingarelli, B.; et al. Exosomal miR-223 Contributes to Mesenchymal Stem Cell-Elicited Cardioprotection in Polymicrobial Sepsis. Sci. Rep. 2015, 5, 13721. [CrossRef] [PubMed]

97. Yu, B.; Kim, H.W.; Gong, M.; Wang, J.; Millard, R.W.; Wang, Y.; Ashraf, M.; Xu, M. Exosomes secreted from GATA-4 overexpressing mesenchymal stem cells serve as a reservoir of anti-apoptotic microRNAs for cardioprotection. Int. J. Cardiol. 2015, 182, 349-360. [CrossRef] [PubMed]

98. Vrijsen, K.R.; Maring, J.A.; Chamuleau, S.A.J.; Verhage, V.; Mol, E.A.; Deddens, J.C.; Metz, C.H.G.; Lodder, K.; van Eeuwijk, E.C.M.; van Dommelen, S.M.; et al. Exosomes from Cardiomyocyte Progenitor Cells and Mesenchymal Stem Cells Stimulate Angiogenesis Via EMMPRIN. Adv. Healthc. Mater. 2016, 5, 2555-2565. [CrossRef] [PubMed]

99. Monguió-Tortajada, M.; Prat-Vidal, C.; Moron-Font, M.; Clos-Sansalvador, M.; Calle, A.; Gastelurrutia, P.; Cserkoova, A.; Morancho, A.; Ramírez, M.Á.; Rosell, A.; et al. Local administration of porcine immunomodulatory, chemotactic and angiogenic extracellular vesicles using engineered cardiac scaffolds for myocardial infarction. Bioact. Mater. 2021, 6, 3314-3327. [CrossRef] [PubMed] 